\title{
Synthesis and Anticonvulsant Activity (Chemo Shock) of Phenothiazine Amino Acid Derivatives
}

\author{
PANDEYA SURENDRA NATH ${ }^{\mathrm{a}}$, YADAV MEENA $\mathrm{K}^{* \mathrm{a}}$ and TRIPATHI LAXMI
}

${ }^{\mathrm{a}}$ Department of Pharmaceutical Sciences, Saroj Institute of Technology and Management, Ahimamau, Sultanpur Road, Lucknow-226002(U.P) India

${ }^{\mathrm{b}}$ S.D.College of Pharmacy and Vocational Studiesdepartment of Pharmacy, Muzaffar Nagar, U.P. 251001, India

meenayadav82@gmail.com

Received 2 August 2012 / Accepted 4 September 2012

\begin{abstract}
Amino acid derivatives of phenothiazine scaffold were synthesized and screened for their anticonvulsants activity against chemo shock induced screening to study the mechanism of action of anticonvulsants. Strychnine, thiosemicarbazide and 4-aminopyridine were used for induction of seizures. Rotorod test was used to study the neurotoxicity profile of these compounds. All these compounds protected against strychnine and thiosemicarbazide $(20 \mathrm{mg} / \mathrm{kg})$ induced seizures at a dose of $30 \mathrm{mg} / \mathrm{kg}$ up to $2 \mathrm{~h}$. In case of 4-aminopyridine $(13.3 \mathrm{mg} / \mathrm{kg})$ induced seizure, protection was observed only up to 15 minute which was followed by death of the animals.
\end{abstract}

Keywords: Phenothiazine, Amino acids, Strychnine, Thiosemicarbazide, 4-Aminopyridine, Anticonvulsants

\section{Introduction}

Epilepsy is a common and diverse set of chronic neurological disorder characterized by seizures. It affects 2.5 millions Americans. More than 180,000 people are diagnosed with epilepsy every year. The first drug phenytoin has been a triumph of modern medicine. The development of newer medication, especially carbamazepine, oxacarbamazepine, vigabatrine and lamotrigine are used to control epilepsy. A continuing effort is being made to find safer, more effective treatments for epilepsy. Recently functionalized amino acids have been screened for anticonvulsant activity. This has resulted in the research of lacosamide (Vimpat) ${ }^{1}$ to treat epilepsy. Phenothiazine is an important template for CNS depressant (antipsychotic drugs) ${ }^{2}$.

Chemical model of epilepsy is based on the application of withdrawal from chemical substances with consequent of appearance of epileptic sympatomatology. Different chemical model of epilepsy which mimic different clinical seizure type, dealing with different mechanism and acute verses chronic phenomena, were used to screen the synthesized phenothiazine derivatives. Therefore phenothiazine amino acid derivatives can be an important preposition in search of new anticonvulsants. 


\section{Experimental}

A series of phenothiazine amino acid derivatives were synthesized according to the synthetic schemes. Melting points were determined in open capillary tubes on a Jindal melting point apparatus and are uncorrected. The homogeneity of the compounds was monitored by thin layer chromatography (TLC) using silica gel G as stationary phase and visualized by iodine vapours. Solvent system was chloroform: methanol (9:1). Microanalysis of the compounds was done on Perkin-Elmer model 240 analyzer and the values found within $\pm 0.4 \%$ of the theoretical values. ${ }^{1} \mathrm{H}$ NMR spectra were recorded on DPX-300 NMR spectrometer and BRUKER-400 Ultra shield $^{\mathrm{TM}}$ spectrometer. Chemical shifts $(\delta)$ are expressed in ppm relative to tetramethylsilane (TMS). The FT-IR spectra were recorded in $\mathrm{KBr}$ pellets on BIO-RAD FTS, FT-IR spectrophotometer. All the chemicals and solvents used were procured from Merck (India), S.D.Fine Chemicals (India) \& Rankem (India). The physical constants and spectral data of the synthesized compounds are presented in Table 1 and Table 2, respectively.

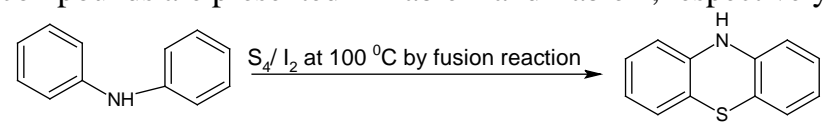

Diphenylamine

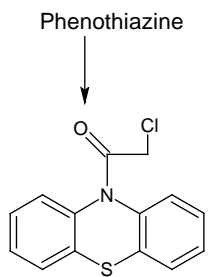

2-Oxo-2-phenothiazine-10-yl-ethyl amino-acetic acid

2-chloro-1-phenothiazin-10-yl-ethanone
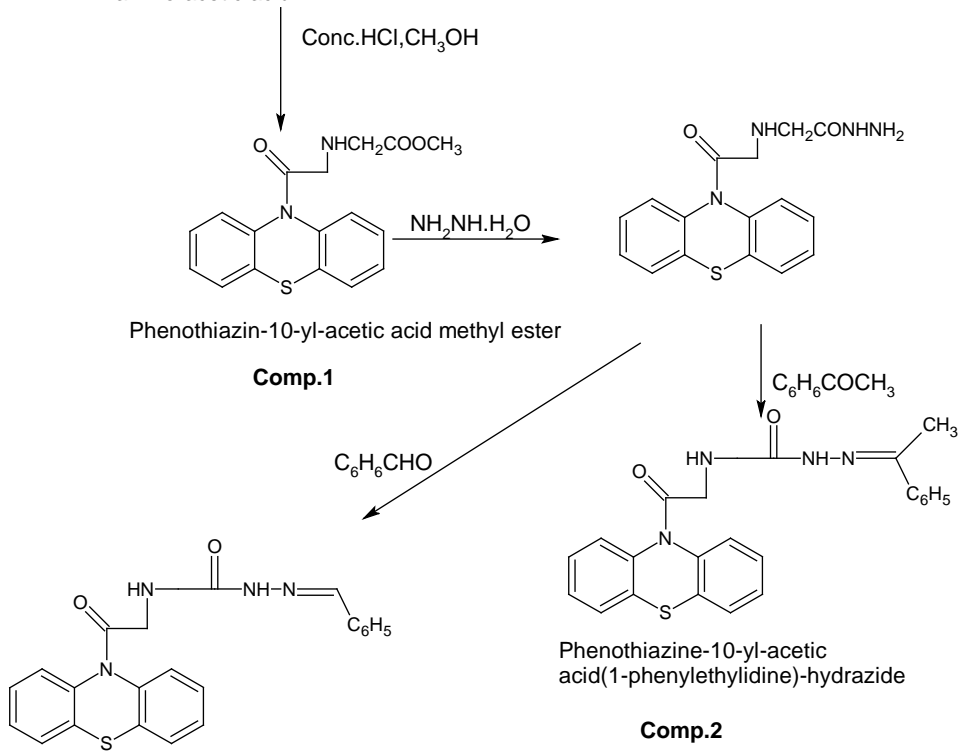

Phenothiazine-10-yl-acetic acid(1-phenylethylidine)-hydrazide

Comp.2

Phenothiazine-10-yl-acetic acid benzylidine-hydrazide 


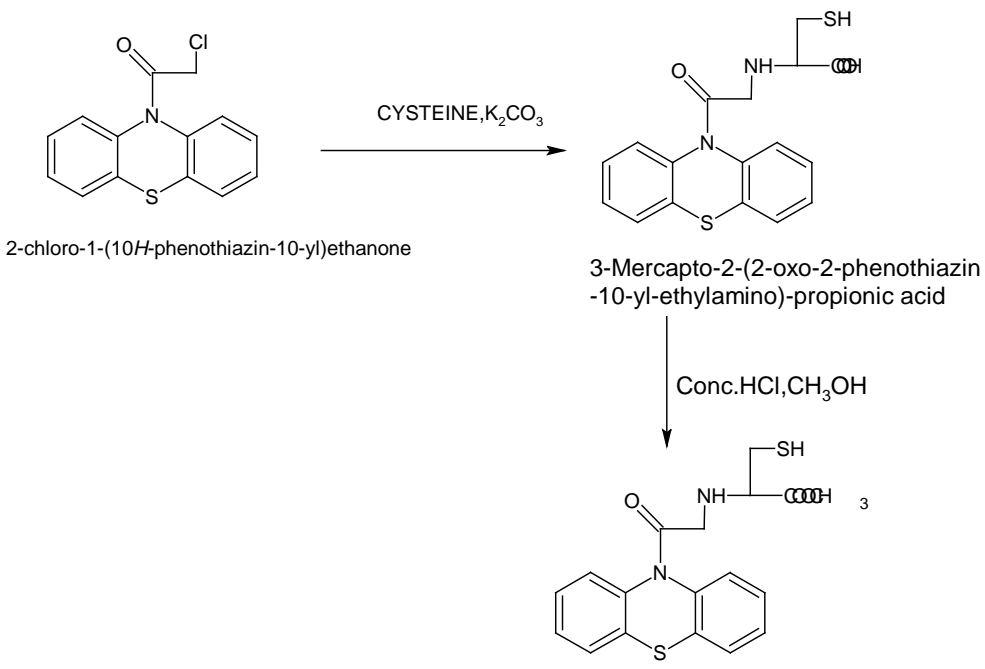

3-Mercapto-2-phenothiazine-10-yl-propionic acid methyl ester

Comp.4

Scheme 2

Table 1. Physicochemical properties of phenothiazine derivatives

\begin{tabular}{ccccccc}
\hline Compounds & Mol. formula & Mol.wt. & M.P. ${ }^{0} \mathrm{C}$ & $\begin{array}{c}\mathrm{R}_{\mathrm{f}} \\
\text { value }\end{array}$ & C log P & $\begin{array}{c}\% \\
\text { Yield }\end{array}$ \\
\hline Comp.1 & $\mathrm{C}_{19} \mathrm{H}_{13} \mathrm{~N}_{3} \mathrm{OS}$ & 271.33 & $240-241$ & 0.72 & 4.191 & 78 \\
Comp.2 & $\mathrm{C}_{24} \mathrm{H}_{22} \mathrm{~N}_{4} \mathrm{O}_{2} \mathrm{~S}$ & 328.39 & $30-35$ & 0.68 & 1.0656 & 76.31 \\
Comp.3 & $\mathrm{C}_{25} \mathrm{H}_{24} \mathrm{~N}_{4} \mathrm{O}_{2} \mathrm{~S}$ & 359.49 & $70-72$ & 0.63 & 6.048 & 82 \\
Comp.4 & $\mathrm{C}_{18} \mathrm{H}_{18} \mathrm{~N}_{2} \mathrm{O}_{3} \mathrm{~S}_{2}$ & 317.43 & $50-55$ & 0.53 & 4.323 & 90.23 \\
\hline
\end{tabular}

Table 2. Spectral data of compounds

\begin{tabular}{|c|c|c|c|}
\hline $\begin{array}{l}\text { Compounds } \\
\text { Code }\end{array}$ & $\mathrm{IR}(\mathrm{KBr}), \mathrm{cm}^{-1}$ & $\begin{array}{c}{ }^{1} \mathrm{H} \mathrm{NMR}\left(\mathrm{CDCl}_{3}\right): \\
\delta, \mathrm{ppm}\end{array}$ & $\begin{array}{c}\text { Elemental } \\
\text { analysis, \% }\end{array}$ \\
\hline \multirow{7}{*}{ Comp.1 } & $\mathrm{IR}(\mathrm{KBr}) \mathrm{cm}^{-1}$ : & ${ }^{1} \mathrm{H}$ NMR $\left(\mathrm{CDCl}_{3}\right): \delta$ & Cal.:C(68.86), \\
\hline & $1650(\mathrm{C}=\mathrm{O}), 2914\left(\mathrm{CH}_{2}\right)$ & 6.68-6.95 & H(3.95), N(12.68), \\
\hline & $3082(\mathrm{~N}-\mathrm{H}), 1588(\mathrm{C}=\mathrm{C}$ & (m,8H,Phenothiazine), & Found:C(68.33), \\
\hline & aromatic),1432-1442 & 4.02(s,2H,methylene), & $\mathrm{H}(4.15), \mathrm{N}(12.85)$ \\
\hline & $(\mathrm{C}=\mathrm{N}), 3172$ & 3.67(s,3H,methyl), & - \\
\hline & (aromatic),1582-1630 & 3.49(s,2h,methylene), & \\
\hline & $\begin{array}{l}\text { (Phenothiazine Ring). } \\
\text { IR }(\mathrm{KBr}) \mathrm{cm}^{-1} \text {. }\end{array}$ & $\begin{array}{l}2.0(\mathrm{~s}, \mathrm{NH}, \text { amine }) \\
{ }^{1} \mathrm{H} \text { NMR }\left(\mathrm{CDCl}_{3}\right): \delta\end{array}$ & $\mathrm{Ca}$ \\
\hline \multirow[t]{7}{*}{ Comp.2 } & $1632(\mathrm{C}=\mathrm{O}), 2930\left(\mathrm{CH}_{2}\right)$ & 6.69-7.42(m,8H, & $\mathrm{H}(4.63) \mathrm{N}(12.87)$ \\
\hline & $3060(\mathrm{~N}-\mathrm{H}), 1588(\mathrm{C}=\mathrm{C}$ & Phenothiazine), & Found:C \\
\hline & aromatic),1415-1432 & 2.0(s,NH,amine), & (67.30),H(4.85), \\
\hline & $(\mathrm{C}=\mathrm{N}), 3345(\mathrm{Ar}-\mathrm{H})$, & 1.23(s,3H,methyl), & $\mathrm{N}(12.85)$ \\
\hline & $1540-1590$ & 3.42(s,2H,methylene), & \\
\hline & (Phenothiazine Ring). & 3.67(s,H,methine), & \\
\hline & & 11(s,OH carboxylic acid), & \\
\hline
\end{tabular}




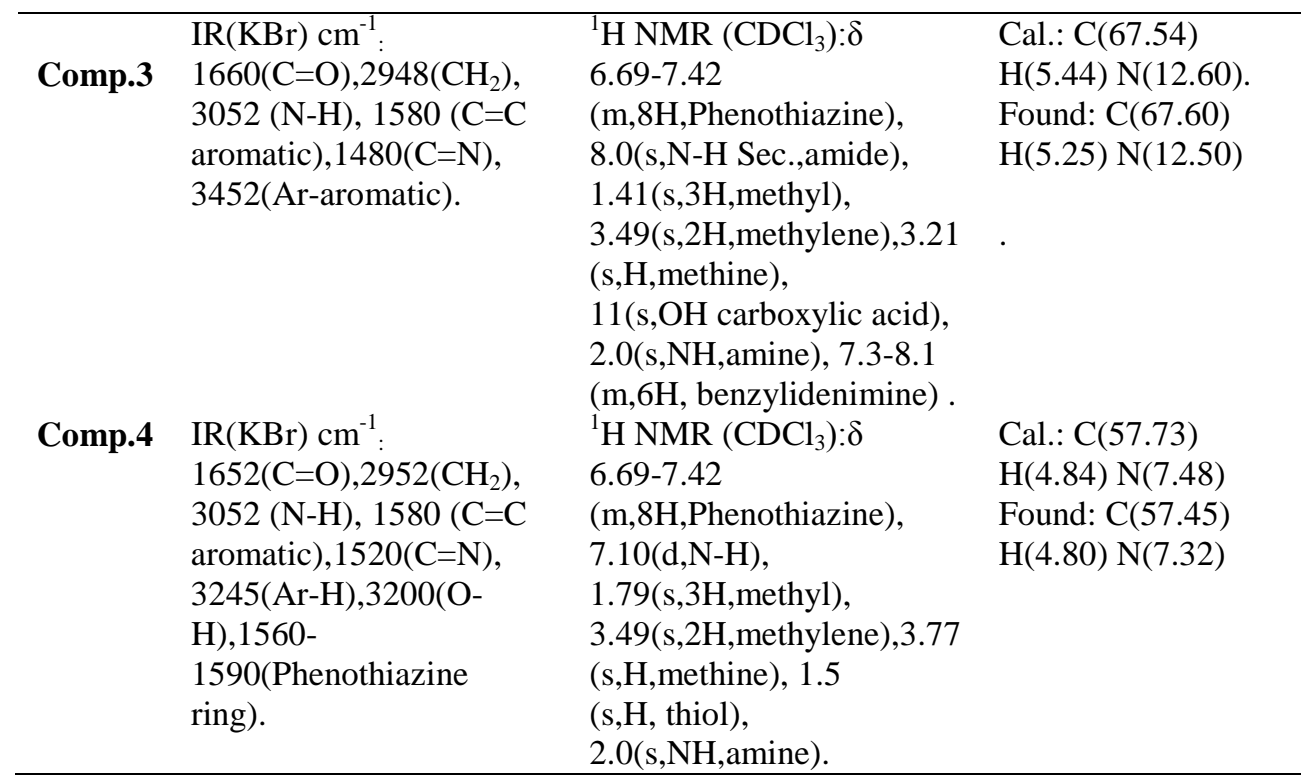

Table 3. Anticonvulsant activity and neurotoxicity data of phenothiazine derivatives

\begin{tabular}{|c|c|c|c|c|c|c|c|c|c|c|}
\hline \multirow[t]{2}{*}{$\begin{array}{l}\text { Compd } \\
\text { Code }\end{array}$} & \multicolumn{3}{|c|}{$\begin{array}{l}\text { Strychnine induced } \\
\text { model }\end{array}$} & \multicolumn{3}{|c|}{$\begin{array}{l}\text { Thiosemicarbazide } \\
\text { induced model }\end{array}$} & \multicolumn{2}{|c|}{$\begin{array}{c}\text { 4-Amino } \\
\text { pyridine } \\
\text { induced model }\end{array}$} & \multicolumn{2}{|c|}{$\begin{array}{c}\text { Neurotoxicity } \\
\text { testing }\end{array}$} \\
\hline & $0.5 \mathrm{~h}$ & $1 \mathrm{~h}$ & $2 \mathrm{~h}$ & $0.5 \mathrm{~h}$ & $1 \mathrm{~h}$ & $2 \mathrm{~h}$ & $15 \mathrm{~min}$ & $0.5 \mathrm{~h}$ & $0.5 \mathrm{~h}$ & $4 \mathrm{~h}$ \\
\hline Control & $30 \mathrm{mg}$ & Death & Death & $30 \mathrm{mg}$ & Death & Death & $30 \mathrm{mg}$ & Death & $30 \mathrm{mg}$ & - \\
\hline Comp.1 & $30 \mathrm{mg}$ & $30 \mathrm{mg}$ & $30 \mathrm{mg}$ & $30 \mathrm{mg}$ & 30 mg & Death & $30 \mathrm{mg}$ & Death & $30 \mathrm{mg}$ & - \\
\hline Comp. 2 & $30 \mathrm{mg}$ & $30 \mathrm{mg}$ & $30 \mathrm{mg}$ & $30 \mathrm{mg}$ & 30 mg & Death & $30 \mathrm{mg}$ & Death & $30 \mathrm{mg}$ & - \\
\hline Comp.3 & $30 \mathrm{mg}$ & $30 \mathrm{mg}$ & $30 \mathrm{mg}$ & $30 \mathrm{mg}$ & 30 mg & $30 \mathrm{mg}$ & $30 \mathrm{mg}$ & Death & $30 \mathrm{mg}$ & - \\
\hline Comp.4 & $30 \mathrm{mg}$ & $30 \mathrm{mg}$ & $30 \mathrm{mg}$ & $30 \mathrm{mg}$ & Death & Death & $30 \mathrm{mg}$ & Death & $30 \mathrm{mg}$ & - \\
\hline Diazepam & $10 \mathrm{mg}$ & $10 \mathrm{mg}$ & $10 \mathrm{mg}$ & $10 \mathrm{mg}$ & $10 \mathrm{mg}$ & $10 \mathrm{mg}$ & & & & - \\
\hline Phenytoin & & & & & & & $30 \mathrm{mg}$ & Death & $30 \mathrm{mg}$ & - \\
\hline
\end{tabular}

\section{Synthetic procedure}

Phenothiazine was prepared by $0.05 \mathrm{M}$ diphenylamine as starting material in $89 \%$ yield through the classical condensation by fusion with power sulfur. Product obtained was wash with $\mathrm{KI} \& \mathrm{CHCl}_{3}$. Then $0.01 \mathrm{M}$ solution of $10-\mathrm{H}$ phenothiazine was prepared, added $50 \mathrm{~mL}$ dry benzene and chloroacetyl chloride $(0.01 \mathrm{~mol})$ at $0-5{ }^{0} \mathrm{C}$. Further reaction mixture was refluxed $3-4 \mathrm{~h}$ at $50-60{ }^{\circ} \mathrm{C}$ and resulting mixture distilled off. Then mixture poured on ice cold water, solid obtained, recrystallized from ether. After that $\mathrm{N}$-(2Chloroacetyl) phenothiazine was treated with glycine and cysteine simultaneously in the presence of $\mathrm{K}_{2} \mathrm{CO}_{3}$ and refluxed for 3-4 $\mathrm{h}$ at 50-60 ${ }^{\circ} \mathrm{C}$. Further recrystallized with acetone. Then Glycine and cysteine derivative of phenothiazine were treated with methanol in presence of acid, refluxed for $2 \mathrm{~h}$ at $50-60{ }^{\circ} \mathrm{C}$ and recrystallized with ethanol. Finally Schiff bases of these derivatives were prepared by reaction of different aldehyde and ketones with hydrazine hydrate. 


\section{Anticonvulsant activity}

\section{Animals}

The healthy Swiss albino mice of both sexes weighing 25-30 g were taken for the study. The animals were kept in large spacious hygienic cages during the course of experimental period. The animals had free access to standard commercial diet and water ad libitum and were kept in rooms maintained at $22 \pm 1{ }^{0} \mathrm{C}$ with $12 \mathrm{~h}$ light dark cycle.

The anticonvulsant screening of the final compounds was done according to the protocols of the anticonvulsant drug development (ADD) programme ${ }^{3}$.

\section{Procedure}

\section{Strychnine induced model}

Mice of either sex with a weight of 25-30 g were treated with the test compounds or the standard (e.g. diazepam $10 \mathrm{mg} / \mathrm{kg}$ i.p.) by oral or intraperitoneal administration. Controls received the vehicle only.30 minute after i.p. treatment the animals were injected with a subcutaneous dose of $1 \mathrm{mg} / \mathrm{kg}$ strychnine. The occurrence of clonic seizures, tonic seizures and death or recovery was recorded after $0.5 \mathrm{~h}, 1 \mathrm{~h}, 2 \mathrm{~h}$ and 4 h respectively ${ }^{4}$.

\section{Thiosemicarbazide induced model}

Mice of either sex with a weight of 25-30 g were treated with the test compounds or the standard (e.g. diazepam $10 \mathrm{mg} / \mathrm{kg}$ i.p.) by oral or intraperitoneal administration. Controls received the vehicle only.30 minute after i.p. treatment the animals were injected with a subcutaneous dose of $20 \mathrm{mg} / \mathrm{kg}$ thiosemicarbazide. The occurrence of clonic seizures, tonic seizures and death or recovery was recorded after $0.5 \mathrm{~h}, 1 \mathrm{~h}, 2 \mathrm{~h}$ and 4 h respectively ${ }^{4-6}$.

\section{4-Amino pyridine induced model Neurotoxicity testing}

Male NIH Swiss mice weighing 25-30 g were allowed to acclimatize with free access to food and water for a 24-h period before testing. Test drug were administered at a dose of $30 \mathrm{mg} / \mathrm{kg}$ body weight intraperitonially, $30 \mathrm{~min}$ prior to subcutaneous injection of 4-aminopyridine at a dose of $13.3 \mathrm{mg} / \mathrm{kg}$. Control s injection of 4-aminopyridine at a dose of $13.3 \mathrm{mg} / \mathrm{kg}$. Controls treated with 4-aminopyridine only exhibit characteristic behavioral signs, such as hyper reactivity, trembling, intermitted forelimb/hindlimb clones followed by hindlimb extension, tonic seizures, opisthotonus and death. The standard drug phenytoin at a dose of $30 \mathrm{mg} / \mathrm{kg}$ body weight was taken for comparison ${ }^{7-9}$.

\section{Neurotoxicity screening}

Activity of the drugs interfering with motor coordination was checked by the rotorod test. The mice were trained to stay on an accelerating rotorod that rotate at 6 revolutions per minute. The rod diameter was $3.2 \mathrm{~cm}$ Neurotoxicity was indicated by the inability of the animal to maintain equilibrium on the rod for at least $1 \mathrm{~min}$ in each of three trials. The dose, at which the animals were unable to grasp the rotorod, was determined ${ }^{10-11}$. The compounds were found to be non-neurotoxic at a dose of $30 \mathrm{mg} / \mathrm{kg}$ body weight.

All the derivatives were active against strychnine induced seizure at $30 \mathrm{mg} / \mathrm{kg}$ dose upto $2 \mathrm{~h}$ of compounds administration. This indicates that the compounds may be acting through modulation of glycine receptor. Activity against 4-amino pyridine induced model indicates their antagonism via $\mathrm{K}+$ channel. The controls protected only upto 15 minutes, which was followed by death in all cases. 


\section{Results and Discussion}

All the synthesized compounds were evaluated for their anticonvulsant activity using various chemical induced convulsion models on albino mice (20-25 g.). PEG-400 was used as vehicle and diazepam $10 \mathrm{mg} / \mathrm{kg}$ body weight as a standard drug. All the synthesized derivative were evaluated at the dose of $30 \mathrm{mg} / \mathrm{kg}$ body weight and have shown good anticonvulsant activity and the compounds Comp.2 \& Comp.3 were found to be most active amongst all the screened compounds using strychnine induced model and against thiosemicarbazide induced model respectively and none of the compounds showed anticonvulsant activity using 4-amino pyridine. The phenothiazine derivatives substituted with glycine were more potent anticonvulsants.

The results showed that most of the derivatives were active anticonvulsant against hydrazides as convulsant. They share a common action mainly through facilitation of GABA synthesis which was prevented by hydrazides via inhibition of glutamic acid decarboxylase. The derivatives were found to act as convulsant via $\mathrm{K}+$ channel antagonism.

\section{Conclusion}

Thus the compounds have a broad range of mechanism of action through glycine reaction, facilitation of GABA synthesis and via $\mathrm{K}^{+}$channel antagonism. Further the compounds were non-neurotoxic at $30 \mathrm{mg} / \mathrm{kg}$ unto half an hour.

\section{Acknowledgement}

The author is thankful to the director, Saroj Institute of technology and management, Lucknow, India for providing necessary laboratory facilities. Athour is also thanks to Head, Sophisticated Analytical Instrumental Facility Department, Central Drug Research Institute (CDRI) for providing spectroscopic analysis facilities.

\section{References}

1. Sinha S, Pandeya S N, Verma A and Yadav D, Int J Res Ayu Pharm., 2011, 2(4), 1130-1137.

2. Errington A C, Storhr T, Heers C and Lees G, Mol Pharmacol., 2008, 73(1), 157-169, DOI: 10.1124/mole. 107.03a867.

3. Krall R L, Penry J K, White B G, Kupferberg H J and Swinyard E A, Epilepsia, 1978; 19, 409-428.

4. Vogel H G, Drug Discovery and Evaluation: Pharmacological assay, Berlin: Springer Verlag, New York, 2002, 696-716.

5. $\quad$ Nishie K, Weary M and Berger A, J Pharmacol Exp Ther., 1996, 153(3), 387-395.

6. $\quad$ Wada J A and Asakura T, Exp Neuro., 1969, 24(1), 19-37.

7. Yamaguchi S I and Rogawski M A, Epilepsy Res., 1992, 11, 9-16.

8. Oyama Y, Brain Res., 1987, 409(2), 243-249.

9. $\quad$ Grafe P, Galvan M and Ten Bruggencate G, Brain Res., 1982, 241(1), 75-86.

10. Krall R L, Penry J K, White B G, Kupferberg H J and Swinyard E A, Epilepsia, 1978, 19, 409-428.

11. Bhragual D D, Kumar N and Drabu S, J Chem Pharm Res., 2010, 2(2), 345-349. 